\title{
Dossiê/Dossier/Dosier
}

\section{História oral: narrativas de memória, acervos e a pesquisa em História da Educação}

\author{
Oral history: narratives from memory, collections, \\ and research in History of Education \\ Historia oral: narrativas de memoria, colecciones y la \\ investigación en Historia de la Educación
}

\author{
ORGANIZAÇÃO \\ DóRis BitTencourt ALmeidA ${ }^{1}$ E LuCIANE SGARBi S. GRAZZIOTIN ${ }^{2}$
}

\section{Apresentação}

\begin{abstract}
"Será preciso, contudo, não esquecer que tudo tem início não nos arquivos, mas com o testemunho, e que, apesar da carência principal de confiabilidade do testemunho, não temos nada melhor que o testemunho, em última análise, para assegurar-nos de que algo aconteceu." (RICOEUR, 2007, p. 156).
\end{abstract}

A afirmativa de Ricoeur propõe a reflexão acerca do valor da memória oral no processo de produção da narrativa historiográfica. No meio acadêmico, percebemos o quanto pode ser potente pesquisar a História da Educação, tendo como aporte metodológico a História Oral. Tal evidência nos mobilizou a organizar esse dossiê que reúne uma comunidade de pesquisadoras que se preocupam em pensar a educação, tendo como principal referente a memória oral como documento.

\footnotetext{
${ }^{1}$ Doutora em Educação pelo Programa de Pós-graduação em Educação da Universidade Federal do Rio Grande do Sul. Professora Adjunta IV de História da Educação da Faculdade de Educação da Universidade Federal do Rio Grande do Sul. E-mail: almeida.doris@gmail.com

${ }^{2}$ Doutora em Educação pela Pontifícia Universidade Católica do Rio Grande do Sul. Professora do Programa de Pós-Graduação em Educação da Universidade do Vale do Rio dos Sinos. E-mail: lsgarbi@unisinos.br
} 
Entendemos que essa metodologia se constitui em um importante recurso para compreensão de tempos pretéritos. Por meio dela, podem ser investigadas múltiplas questões, sobretudo relacionadas à apropriação e difusão de modelos pedagógicos, práticas educativas e aspectos que tratem, de modo geral, dos itinerários dos agentes da educação.

Qual a importância da História Oral na contemporaneidade? O que significa trabalhar nessa perspectiva? Em um passado recente, preponderava um entendimento de que através dessa metodologia seria possível recuperar o passado por meio da voz dos oprimidos, daqueles relegados ao silêncio, devolvendo a eles o lugar que lhes havia sido negado nas tramas da História. Nas últimas décadas, diante das discussões propostas pela História Cultural, com relação à ampliação da noção de documento, ressignificou-se o papel da História Oral na pesquisa historiográfica. As concepções iniciais, importantes naquele contexto, foram problematizadas, em especial, o poder irrefutável conferido ao testemunho em primeira pessoa. Beatriz Sarlo questiona essa infalibilidade, mas defende a legitimidade da História Oral, afinada às perspectivas da História Social e Cultural. Neste sentido, desloca-se o foco das pesquisas "para as margens das sociedades modernas, modificando a noção de sujeito e a hierarquia dos fatos, destacando os pormenores cotidianos, articulados numa poética do detalhe e do concreto" (Sarlo, 2007). Portanto, o que constituiu a História Oral no passado não precisa ser descartado em sua totalidade, ou seja, há que se dizer que o trabalho com essa metodologia, por estar atrelado às subjetividades de cada sujeito entrevistado, traz consigo o princípio de democratização dos agentes da História.

No segundo quartel do século XX, os debates sobre narrativas de memória e sua relação com a História da Educação adquiriram certa visibilidade e, paulatinamente, ofereceram perspectivas de inteligibilidade para o passado das instituições escolares, das práticas educativas, do cotidiano da sala de aula, das memórias de professores e alunos, entre outros temas. A História da Educação, como zona de fronteira que se aproxima das teorias da História, busca construir sua identidade disciplinar, reforçar suas ligações com outras ciências, abrir-se às novas realidades e diversificar as abordagens. Atualmente, a pesquisa neste campo de conhecimento inova em relação à sua compreensão do passado recente e, nesse contexto, são valorizadas as memórias orais da educação/escolarização.

Em uma tentativa de articular a História da Educação e os pressupostos que norteiam a História Oral, apresentamos a ideia de um dossiê que tematize as questões mencionadas. A proposta é publicar estudos que examinem a complexidade da memória produzida pela oralidade, em suas distintas interfaces com a História da Educação. Desse modo, tem-se como objetivo oportunizar espaço de diálogo para que pesquisadores possam expor suas investigações inseridas nessas interfaces.

Alícia Civera, por meio das narrativas de três professores exilados pela Ditadura Franquista, analisa a construção de uma memória escolar relacionada aos modelos pedagógicos da Escola Normal Espanhola, nos anos quarenta do século XX. Ao mobilizar aspectos relacionados às especificidades da História Oral, a autora considera essa metodologia um modo de capturar as tradições pedagógicas, sem que necessariamente haja uma explicitação racional a respeito. No entanto, percebe que essas tradições e formas de atuar dos estudantes estão representadas em suas identidades, em seus afetos. 
Com o objetivo de analisar itinerários formativos e práticas educativas vivenciadas no ensino primário em escolas de Caxias do Sul/RS, Terciane Luchese, a partir das memórias de docentes nascidos nas duas primeiras décadas do século XX, busca compreender os fazeres e os saberes de cinco professoras, todas elas formadas para atuarem no ensino primário. As memórias, somadas a outros documentos, compõem o campo empírico que, com o apoio teórico da História Cultural, permitem tematizar as práticas educativas de docentes entre os anos 1920 e 1960.

$\mathrm{O}$ acervo de fontes orais intitulado "Projeto Memória Lassalista", o qual integra as coleções de documentos sob a guarda do Museu Histórico La Salle (MAHLS) do Unilasalle Canoas, é o objeto de estudo de Cleusa Garbin. Nessa pesquisa, a autora problematiza o depositário da coleção, as bases históricas e teóricas do Projeto, a sua constituição e operacionalização e as possibilidades de utilização. Além disso, estabelece uma discussão acerca das perspectivas futuras do Projeto. As complexidades e os desafios em relação à produção, tratamento, preservação e socialização de acervos orais são tematizados no artigo.

Claricia Otto, no período que compreende os anos 1930 e 1960, discute os resultados de uma pesquisa sobre a ação docente de religiosas da atual Congregação das Irmãs Catequistas Franciscanas (CICAF), em escolas primárias de Santa Catarina. Para tanto, se vale de memórias de dez religiosas, professoras aposentadas dessa Congregação. A análise evidenciou aspectos do cotidiano escolar daquele período e entendeu que as professoras tiveram papel fundamental na constituição de determinada cultura escolar, especialmente no que concerne ao vínculo com a religião católica na escola laica.

Uma discussão acerca de professores leigos que atuaram em escolas isoladas e multisseriadas nas décadas de 1940-1960 no município de Pelotas/RS é o que propõem Patrícia Weiduschadt e Giana Lange do Amaral. A análise se constituiu a partir de quatro entrevistas que tematizam o pertencimento docente à etnia pomerana alemã e a religião luterana. Neste sentido, os conceitos de memória e identidade problematizam as memórias coletivas, reelaboradas no tempo presente.

Por fim, o artigo "Memórias de escola em colônias agrícolas judaicas no Rio Grande do Sul: narrativas orais do acervo do Instituto Cultural Marc Chagal (1904 - 1930)" investiga alguns aspectos acerca dos processos de escolarização dos primeiros imigrantes judeus fixados em colônias agrícolas no RS. Por meio das narrativas de memória de sujeitos que viveram sua infância naquelas comunidades, procura-se recompor uma História acerca das primeiras escolas naqueles espaço e tempo determinados. As narrativas visibilizam elementos, tais como o significado da escola para o povo judeu, as dificuldades de acesso e locomoção à escola, a presença de crianças de origem não judia na escola e, sobretudo, o papel da Jewish Colonization Association, conhecida no Brasil como ICA, e seu papel determinante no apoio aos processos de escolarização do Imigrantes Judeus.

\section{Referências}

RICOEUR, Paul. A memória, a história, o esquecimento. Campinas: Editora da UNICAMP, 2007.

SARLO, Beatriz. Tempo passado: cultura da memória e guinada subjetiva. São Paulo: Cia. das Letras, 2007. 